\title{
The Relationship Between Corporate Social Responsibility Disclosures and Corporate Value: Evidence from Listed Companies on Vietnam's Stock Market
}

\author{
Hang Thi Thuy Ta \\ University of Labor and Social Affairs, Vietnam \\ E-mail: hangulsa@gmail.com
}

Ngoc Thi Bui (Corresponding author)

$\mathrm{PhD}$ at the Faculty of Accountancy, University of Labor and Social Affairs, Vietnam

E-mail: buithingoc.ldxh@gmail.com

Oanh Thi Tu Le

University of Labor and Social Affairs, Vietnam

E-mail: oanhletu@gmail.com

Received: August 30, 2018 Accepted: September 23, 2018 Published: November 7, 2018

doi:10.5296/ifb.v5i2.13868

URL: http://dx.doi.org/10.5296/ifb.v5i2.13868

\begin{abstract}
Information on corporate social responsibility is part of non-financial information which shows the interaction of business with society and the living environment, specifically, information on environmental pollution control, human rights, product liability, labor relations, charitable activities. Corporate social responsibility disclosure is considered a means to help enterprises increase their reputation, enhance their competitiveness, and strengthen relationships with stakeholders. The sharing of this information has become a global business trend. This study uses Two-Stage Least Squares (2SLS) Regression Analysis to examine the reciprocal relationship between corporate social responsibility disclosures and corporate value represented by the Tobin'Q ratio through a sample of 43 listed firms on
\end{abstract}




\section{Macrothink}

International Finance and Banking ISSN 2374-2089 2018, Vol. 5, No. 2

Vietnam's stock market during the period 2006-2016 with 473 observations. The results show that there is a positive reciprocal relationship between corporate social responsibility disclosures and corporate value Tobin'Q.

Keywords: corporate social responsibility disclosures, financial effectiveness, corporate value Tobin'Q 


\section{Introduction}

Nowadays, corporate social responsibility has become a global trend, so the reporting of such issues has also evolved into a major concern for enterprises. Corporate social responsibility disclosures (CSRD) indicate that an enterprise has implemented activities to protect living environment, the rights of the employees, as well as carried out responsibilities to communities. CSRD is an important tool to communicate information on corporate social responsibility activities of enterprises to stakeholders. Gray et al. (1995) suggested that CSRD is a process providing information about environmental and social impacts of an organization's economic activities. It relates to accountability of organizations (especially enterprises), as in addition to providing financial information for shareholders, enterprises also have the responsibility to provide other information to stakeholders and interested groups.

A number of studies have shown that CSRD are beneficial to enterprises such as enhancing images, reputations and brands, helping businesses attract investment, improving financial efficiency, attracting talent (Alexander et al. 1978; Belkaoui, 1976). This is confirmed by a study of KPMG in 2013 with a sample of 4.100 enterprises among which more than $70 \%$ of enterprises disclosed social responsibility information in their activity reports. Thus, many companies consider the implementation and disclosure of corporate social responsibility as their business strategy (Belkaoui, 1976).

Furthermore, CSRD is also considered a tool for evaluating the social efficiency of an enterprise. As a result, many companies voluntarily disclose information about their activities relating to ethics, corporate governance, social and environmental issues. In addition, CSRD is seen as a tool in increasing transparency and showing social responsibility (Berthelot, 2012).

In Vietnam, the practice and disclosure of corporate social responsibility have gradually been paid more attention by enterprises due to the need of satisfying international standards and integration requirements. In addition, pressure from the community requires Vietnamese enterprises to be more responsible after a series of scandals over the use of child labor, the release of waste into the environment, low-quality products. Therefore, corporate social responsibility and CSRD have become the subject of research by many Vietnamese researchers. However, these studies various results due to different contexts, times and methods of measuring financial performance.

The purpose of this study is to identify the method of determining corporate value Tobin'Q; prove the relationship between CSRD and corporate value. The research was conducted over a period of 10 years (from 2006 to 2016) to carefully observe the variation of the research problem over time. The research results showed that good implementation of corporate social responsibility will have a positive impact on corporate values. Recently, there is an increasing trend to implement corporate social responsibility. It encourages enterprises to carry out corporate social responsibility and recommends the government to specify legal regulations relating to corporate social responsibility. 
The rest of the study is as follows: Section 2 reviews the literature. Section 3 shows theoretical foundations and develops the research hypotheses. Section 4 elaborates on the research methodology. Section 5 describes the data, analyses the empirical results and presents the research results and discussion. Section 6 concludes the study, indicates the limitations and recommends for future research.

\section{Literature Reviews}

There have been many studies around the world examining the relationship between CSRD and market value of enterprises such as research of Belkaoui (1976), Anderso and Frankle (1980), Robert (1978), Freedman and Stagliano (1991), Blacconiere and Patten (1994), Edmund et al. (1997), Hassel et al. (2005), Alexander and Buchloz (1978), Murray et al. (2005), Berthelotet al. (2012), Clarkson et al. (2013), Klerk (2015), Cahan et al. (2015), Khlif et al. (2015), Saleh et al. (2011), Dewiand Monalisa (2016), Mohammed et al. (2016), Jitaree(2015). The results of these studies are diversified, flexible, and can be divided into three following groups:

\section{Group 1: There is a positive relationship between CSRD and the market value of enterprises}

There has been much evidence showing that the practice and disclosures of corporate social responsibility increases the value of enterprises. These researchs indicate that investors tend to invest in firms which have reports on environmental issues rather than those which do not. Belkaoui (1976) conducted a study on the influence of environmental information on fluctuation of enterprises' stock price, with data from the annual report of 50 US firms in 1970. The results were similar to conclusions of Anderso \& Frankle (1980) in their study on how the disclosures of social information affect the capital markets of enterprises on the Fortune 500 list based on annual reports from July 1972 to August 1973.

Another study of Robert (1978) found that information related to the environment, equity in business, health and safety of employees, community support, product information influenced share price of enterprises through a survey of 287 enterprises on the Fortune 500 list based on annual reports from 1970 to 1976.

Furthermore, research associated with social environment events also showed a positive correlation between CSRD and the market value of enterprises. Freedman \& Stagliano (1991) examined corporate environmental information disclosures of 27 firms in the US textile industry after the US Supreme Court issued regulations tightening cotton dust levels. The study found that, before the issue of cotton dust regulations by the US Supreme Court, stock prices of companies which did not disclose information or disclosed general information assessing the potential impacts of this regulation fell considerably compared to those of companies which had quantitative reports on this issue. This indicates that one of the factors influencing the market is the content and extent of the previously published information regarding new standards or regulations.

Another study that linked to a major event in India of Blacconiere \& Patten (1994) examined reaction of the stock market of 47 US chemical companies (except multinational company Union Carbide) after the leak of chemicals in Bhopal, India caused by Union Carbide, also 
showed similar results. The author explained that the investors have noticed signs of how the company faced the crisis after Bhopal disaster through previously published information. This result is an evidence indicating that if a company discloses "good news", it can overwhelm bad news related to environmental scandals.

In order to better explain the correlation between CSRD and financial performance, many studies have constructed regression equations demonstrating a positive correlation between these two variables, such as Berthelot et al. (2012), Clarkson et al. (2013), Klerk (2015), Cahan et al. (2015). With different methods of measuring level of CSRD in different contexts, these studies gave the same result on the positive correlation between CSRD and the market value of enterprises. Berthelot et al. (2012) conducted a research on listed companies on the stock market of Toronto, Canada concluding that sustainability reports have a positive impact on the market capitalization of firms.

In another context, Clarkson et al. (2013) examined environmental-sensitive companies in the United States and found that the level of CSRD based on Global Reporting Initiative reporting standard had a positive impact on these companies' stock prices. A study at an international level regarding national characteristics and corporate characteristics of Cahan et al. (2015) examined 676 companies from 22 different countries with data on corporate social accountability collected by a survey of KPMG, using a two-stage least squares regression analysis. The authors found that in Anglo - Saxon accounting countries with flexible and highly professional judgment which have international organizations, the impact of corporate social responsibility information on market value Tobin'Q is greater than other countries.

Group 2: There is a negative relationship between CSRD and the market value of enterprises

The positive effects of CSRD on the market value of enterprises are not found in some cases. This is explained by authors as follows:

Firstly, the market is short term and investors do not consider corporate social responsibility information to have long-term benefits on investment decisions.

Secondly, investors find that corporate social responsibility activities increase the cost of business, which is negatively evaluated by investors because the expected return is reduced but the risk is not reduced accordingly.

Edmund et al. (1997) studied 64 US defense companies in 1986 in two groups: 25 companies signing the defense industry initiative on business ethics and conduct (DII) and 39 companies not signing DII. The results indicated that the market reacted negatively to all companies but more negatively to those companies which signed DII. The authors explained that the market responds to DII because investors consider the signing of DII as an acknowledgment of unethical behavior and then the monitoring of these firms will be more emphasized, which negatively affects the opportunity to earn profits of these companies. Hassel et al. (2005) examined 71 listed companies the stock market in Stockholm, Sweden from 1998 to 2000. The Ordinary Least Squares (OLS) model of the study proved a negative impact of environmental information disclosures on market value (MV). 
One weakness of these studies is the use of OLS. Two types of studies on impacts of CSRD on the market value of enterprises and vice versa found a reciprocal relationship between these two variables. When independent variables and dependent variables are interrelated, these variables can make Ordinary Least Squares Regression become faulty, resulting in inaccurate estimates. This indicates that it is necessary to find a method to ensure that the model has reliable estimation. Thus, the author will select the Two-Stage Least Squares regression analysis 2 SLS to overcome this phenomenon with instrument variable chosen as the exogenous variable of the CSRD variable.

Group 3: There are mixed results when examining the relationship between CSRD and the market value of enterprises

In addition, some studies gave mixed results on the relationship between CSRD and market value of enterprises. The reason for such results is that these studies were conducted in different contexts or they considered different aspects of corporate social responsibility. Khlif et al. (2015) studied this relationship with the sample of 14 listed companies in South Africa and 14 listed companies in Morocco. Secondary data was collected from annual reports of these companies during a six-year period from 2004 to 2009. The results showed that when examining overall 28 enterprises in both countries, there was no relationship between CSRD and Tobin'Q. However, the results were different in each market, specifically, CSRD in South Africa had a positive impact on business efficiency and Morocco had an opposite outcome. The authors explained that there were differences between the two legal systems applied by two countries. South Africa applied the Common law while Morocco followed Civil Law. The differences in these two legal systems led to distinctive features of the accounting information system, particularly, in South Africa, professionalism, transparency and law enforcement were more emphasized than in Morocco.

Another study of Verbeeten et al. (2016) examined two aspects environment and society of 130 largest listed companies on the German stock market during the period from 2005 to 2008. The results showed that environmental information does not affect corporate value, but social information has a positive impact on the stock price of the enterprise. This finding suggests that the additional provision of social responsibility information may affect different interest groups. Information about corporate environmental responsibility which satisfies the demand of the government and environmental protection organizations, may have a negative impact on shareholders because it indicates over-investment in environmental activities. Disclosures of social information will build investors' expectations of good financial performance in the future as it indicates both professional human resources department and low risk from systemic events in the wider economy.

In Vietnam, a number of studies have explored the relationship between CSRD and market value of enterprises such as research of Ho \& Yekini (2005), Nguyen et al. (2015), Nguyen \& Trinh (2016), Ho \& Ho (2017). However, with short research time and the use of estimation models such as the Ordinary Least Squares (OLS), Fixed Effects Model (FEM) and Random Effects Model (REM), which may not be reliable if there are endogenous phenomena in the model. Thus, the use of a new estimation method to overcome endogenous phenomena 
among variables with a longer research time is essential to ensure reliable conclusions about the impact of CSRD on corporate value. With this purpose, the authors used the Two-Stage Least Squares regression analysis 2SLS for balanced panel data with 473 observations of 43 firms over an eleven-year period from 2006 to 2016.

\section{Theoretical Foundations and Research Hypothesis}

\subsection{Stakeholder Theory}

Edward (1984) was the first to propose the stakeholder theory. He stated that stakeholder is an important element of corporate social responsibility. Stakeholders of an enterprise include shareholders, suppliers, customers, employees, competitors, activists, media, legislators, scholars, local people, unions, local authorities and the government. He supposed that profit is the result of business rather than the goal of the business. According to Freeman, if a business only concerns the interests of its shareholders, and disregards the needs of other stakeholders who may influence or be influenced by the achievement of enterprises' purposes, the enterprise will probably have to close down. Freeman concluded that the goal of the business is to meet the needs of stakeholders which are anyone affected by the company's decisions, if the company can do this, profit of the company will be generated.

Based on Edward's theory, many studies used the theory's foundation as a basis for explaining the relationship between corporate social responsibility disclosure and corporate value. In the context of corporate governance, the authors argue that a firm with a good corporate social responsibility policy and appropriate managerial behavior will promote employee morale, attract customers, investors and other stakeholders, enhance the image and prestige of the business with investors, exert positive impacts on the financial performance, productivity and create value for the enterprise (Alexander, 1978; Belkaoui, 1976). Another study by Deng et al. (2013) examined the impacts of social responsibility practices on performance efficiency of mergers in the United States. The results showed that acquirees with good corporate socially responsibility bring higher stock returns for acquirers. Servaes and Tamayo (2013) showed that social responsibility adds value to businesses which have customers of good perception.

Thus, according to stakeholder theory, the motivation of enterprises to implement and report corporate social responsibility is to carry out their responsibilities with stakeholders and show that the companies can meet the needs of stakeholders with an expectation that profits will be generated. Provision of corporate social responsibility information reduces asymmetry of information and brings a level playing field for stakeholders, in return, companies expect it to bring certain benefits to the business such as improving image/prestige, attracting investors and improving relationships with stakeholders to obtain support and approval from stakeholders.

\subsection{Legitimacy Theory}

Legitimacy theory which is derived from the concept of organizational legitimacy, is defined by Dowling \& Pfeffer (1975) as follows: "An entity can exist when its value system is congruent with the value system of the larger social system where the entity belongs to. When there is a real or potential disparity between two value systems, the legitimacy of that entity is threatened". By developing the legitimacy theory, Guthrie and Parker (1989) argued that the 
legitimacy theory relates to the power of society. They emphasized that enterprises operating in society must sign a social contract in which the managers agree to fulfill certain social requirements to achieve their goals. The terms of this contract represent the regulations of the law or some terms are not well defined, which depends on expectations of the social communities. Enterprises need to make sure that terms of the contract are not violated in order to maintain a society with legislation in which the organization is permitted to operate.

Legitimacy theory is often used in research to explain the relationship between CSRD and financial performance of enterprises (Jitaree, 2015). According to Toukabri Mohamed et al. (2014) the legitimacy theory explains that CSRD have two basic aspects: the business needs to legitimize its activities and the legitimization process brings benefit to the business. Lopin Kuo and Vivian Yi-Ju Chen (2013) proved benefits of environmentally responsible behaviors with specific evidence from studies such as: easily accessing to resources, attracting more workers and improving communicating conditions with partners, attracting more consumers, limiting the risk of fines due to environmental violations, and having lower cost of capital due to advantages of mobilizing capital on the stock market. Therefore, the legal existence through social responsibility activities has helped businesses improve competitiveness and promote financial performance.

These two theories are primarily used by researchers to explain why managers choose voluntary CSRD. Considering the aspect of cost and benefit, when carrying out corporate social responsibility activities and communicating information about these activities, enterprises will incur certain costs but the benefits may be long-term and valuable. Based on these theories, the authors expect corporates which are aware of implementing corporate social responsibility will improve the corporate image to investors and other stakeholders, contributing to the value of the enterprises. Therefore, the following hypothesis is established:

\section{H1: There is a positive relationship between CSRD and market value of enterprises.}

\section{Methodology}

\subsection{Research Data}

The sample selected by the authors is non-financial companies listed on Vietnam's stock market during the period from 2006 to 2016. The financial and banking enterprises are eliminated because the information provided by these companies is significantly different compared to other types of enterprises. The last sample includes 43 listed companies on the Vietnam stock market after removing financial, credit companies, company delisted during research time, and companies which the authors could not collect their annual reports or sustainable development reports. Thus, 43 enterprises were surveyed in 11 years through the balanced panel data with the total number of observations of $43 \times 11=473$. List of surveyed enterprises, Table 1. 


\section{Macrothink}

International Finance and Banking

ISSN 2374-2089

2018, Vol. 5, No. 2

Table 1. List of companies surveyed

\begin{tabular}{|c|c|c|}
\hline & Code & Company's name \\
\hline 1 & AGF & An Giang Fisheries \\
\hline 2 & BHS & Bien Hoa Sugar \\
\hline 3 & $\mathrm{BMC}$ & Binh Dinh Minerals \\
\hline 4 & BMP & Binh Minh Plastics \\
\hline 5 & CAN & Halong Canfoco \\
\hline 6 & $\mathrm{CII}$ & Ho Chi Minh Infrastructure \\
\hline 7 & CLC & Cat Loi Tobacco \\
\hline 8 & $\mathrm{CYC}$ & Chang Yih Ceramic \\
\hline 9 & DHA & Hoa An Stones and Materials \\
\hline 10 & DHG & Hau Giang Pharmaceutical \\
\hline 11 & $\mathrm{DMC}$ & DOMESCO Medical \\
\hline 12 & DTT & Do Thanh Technology Corp. \\
\hline 13 & FPT & FPT Group \\
\hline 14 & GIL & Binh Thanh Im-export \\
\hline 15 & GMD & Gemadept \\
\hline 16 & HTV & Ha Tien Transport \\
\hline 17 & IMP & Imexpharm Pharmaceutical \\
\hline 18 & ITA & Tan Tao Industrial Park \\
\hline 19 & KDC & Kinh Do Corporation \\
\hline 20 & KHA & Khanh Hoi Investment and Services \\
\hline 21 & KHP & Khanh Hoa Power \\
\hline 22 & MCP & My Chau Printing and Packaging \\
\hline 23 & PGC & Petrolimex Gas \\
\hline 24 & PJT & Petrolimex Tanker \\
\hline 25 & PNC & Phuong Nam Cultural \\
\hline 26 & PPC & Pha Lai Thermal Power \\
\hline 27 & REE & Refrigeration Electrical Engineering \\
\hline 28 & SFC & Saigon Fuel Co. \\
\hline 29 & SFI & Sea and Air Freight International \\
\hline 30 & SGH & Saigon Hotel Corp. \\
\hline 31 & SJD & Can Don Hydro Power \\
\hline 32 & SMC & SMC Trading and Invm't \\
\hline 33 & SSC & Southern Seed JSC \\
\hline 34 & TAC & Tuong An Vegetable Oil \\
\hline 35 & $\mathrm{TDH}$ & Thu Duc House \\
\hline 36 & TNA & Thien Nam Trading and Exim \\
\hline 37 & TS4 & Seafood No 4 \\
\hline 38 & TYA & Taya (Vietnam) electric wire \& cable \\
\hline 39 & VGP & Vegetexco Port \\
\hline 40 & VIP & Viet Nam Petroleum Transport \\
\hline 41 & VIS & Vietnam - Italy Steel \\
\hline 42 & VNM & Vinamilk \\
\hline 43 & VTC & VTC Telecom \\
\hline
\end{tabular}




\subsection{Determining and Measuring Variables}

\subsubsection{Independent Variables_-CSRD}

In this study, the author measured CSRD according to content analysis method, based on annual reports and sustainable development reports of companies. The analyzing process was based on the list of indicators categorized in 4 groups: information about environment-ENV (10 indicators), information about responsibilities to employees-EMP (11indicators), information about responsibilities to community - $\mathrm{COM}$ (6 indicators) and information about responsibilities to customers - CUS (3 indicators). The indicators of information were inherited from studies of Gunsanan et al. (2009), Jitaree (2015), Nguyen (2016) according to Circular 155/2015 of Ministry of Finance of Vietnam issued on 06/10/2015 on guidelines about information disclosures on the stock market.

Steps of the process: Corporate social responsibility is a complex field with many guiding standards, and the selection of standards depends on economic conditions, laws and environment of each country. Therefore, in order to ensure the objectivity of the standard selection process, data collection and survey were conducted in these two following steps.

Step 1, a survey of the 57 listed companies with largest capitals on the Vietnam stock market was conducted, the survey year was 2016. The purpose of this step was to adjust and select the appropriate indicators to conditions and characteristics of Vietnam.

Step 2, based on the indicators of information selected and corrected through step 1, the authors conducted official survey on 43 listed companies with 473 observations. This method has been used by several authors such as Branco \& Rodrigues (2006), Gunawan et al (2009), Saleh et al. (2011), Tjia \& Setiawati (2012), Bayoud et al (2012), Jitaree (2015). After making adjustment in step 1 , the authors developed a list of indicators of corporate social responsibility information are 35 indicators, including 4 groups: ENV (10 indicators), EMP (12 indicators), COM ( 8 indicators) and CUS (5 indicators). List of indicators of corporate social responsibility is shown in Table 2.

Table 2. List of indicators of information about corporate social responsibility

\begin{tabular}{|l|l|}
\hline Symbol & Indicators (observed variables) \\
\hline ENV & Information about environmental responsibility \\
\hline ENV 1 & $\begin{array}{l}\text { The enterprise complies with the law and regulations on prevention of environmental } \\
\text { pollution (including number of times and amount of fines for violation of laws and regulations } \\
\text { on environment) }\end{array}$ \\
\hline ENV 2 & $\begin{array}{l}\text { Information about pollution control activities in the course of business / The report indicates } \\
\text { that the polluting activities of enterprise have been and will be reduced. }\end{array}$ \\
\hline ENV 3 & $\begin{array}{l}\text { Information about conservation of natural resources such as the use of recycled materials, } \\
\text { recycled glass, metal, oil, water, recycled paper }\end{array}$ \\
\hline ENV 4 & $\begin{array}{l}\text { Information about preventing and dealing with environmental consequences due to } \\
\text { production process or exploitation of natural resources, such as soil improvement or } \\
\text { reforestation. }\end{array}$ \\
\hline
\end{tabular}




\begin{tabular}{|c|c|}
\hline ENV 5 & $\begin{array}{l}\text { Information about strategies and supporting activities of enterprises towards environmental } \\
\text { protection / improving the environment }\end{array}$ \\
\hline ENV 6 & Information about environmentally friendly design of infrastructure \\
\hline ENV 7 & Report information on emissions \\
\hline ENV 8 & Report information on discharging waste water \\
\hline ENV 9 & Report information on solid waste disposal \\
\hline ENV 10 & Report on information on environmental protection awards \\
\hline EMP & Information on responsibilities to employees \\
\hline EMP 1 & $\begin{array}{l}\text { Information about enterprises complying with safety standards and working conditions for } \\
\text { employees }\end{array}$ \\
\hline EMP 2 & Information about health care for employees \\
\hline EMP 3 & Information about training, financial support of training courses for employees \\
\hline EMP 4 & Information about recreational activities for employees \\
\hline EMP 5 & $\begin{array}{l}\text { Information about homestay accommodation or plan of homeownership, food and other } \\
\text { benefits for employees }\end{array}$ \\
\hline EMP 6 & Information on compensation for employees, maternity leave, holidays \\
\hline EMP 7 & Information about salaries, bonuses and other benefits for employees \\
\hline EMP 8 & Information about employee stock purchase plan \\
\hline EMP 9 & Information about qualifications and experiences of employees \\
\hline EMP 10 & Information on job stability of current and future employees \\
\hline EMP 11 & $\begin{array}{l}\text { Information about the relationship of enterprise with the union or workers through the } \\
\text { movement of culture, sports, emulation of production }\end{array}$ \\
\hline EMP 12 & Information about discrimination at workplace and jobs \\
\hline COM & Information about responsibilities to community \\
\hline COM 1 & $\begin{array}{l}\text { Information about charitable activities with money, products / services or corporate } \\
\text { employees participating in these activities, community events such as sports, culture and arts. }\end{array}$ \\
\hline COM 2 & $\begin{array}{l}\text { Information about employment opportunities for students, special people such as ethnic } \\
\text { minorities, children of war invalids, disabled people, victims of Agent Orange and those in } \\
\text { difficult circumstances. }\end{array}$ \\
\hline COM 3 & $\begin{array}{l}\text { Information about sponsoring projects of community health and providing health information } \\
\text { to the Community / Supporting medical research }\end{array}$ \\
\hline $\mathrm{COM} 4$ & Information about establishing education funds or scholarships or educational conferences \\
\hline COM 5 & $\begin{array}{l}\text { Information about supporting victims of natural disasters, family under preferential treatment } \\
\text { policy, victims of Agent Orange, contributions to charity, sponsoring disabled children and } \\
\text { orphans }\end{array}$ \\
\hline COM 6 & $\begin{array}{l}\text { Information about supporting the development of industries, economic projects bringing } \\
\text { benefits to the local }\end{array}$ \\
\hline COM 7 & Creating jobs and developing skills for local people \\
\hline COM 8 & Contribution to building electricity infrastructure, roads, schools and stations for localities \\
\hline CUS & Information about responsibilities to customers \\
\hline CUS 1 & Information about product safety of enterprise \\
\hline CUS 2 & Information about product quality \\
\hline CUS 3 & Information about production and product development \\
\hline CUS 4 & $\begin{array}{l}\text { Commitment to quality, product safety and supporting when having trouble using the } \\
\text { products }\end{array}$ \\
\hline CUS 5 & Building customer relationships, collecting contributions and resolving customer complaints \\
\hline
\end{tabular}




\section{Macrothink}

Technical process: First the authors read reports and found information related to the indicators in the evaluation list. If an enterprise did not disclose the $\mathrm{i}^{\text {th }}$ indicator, the label is " 0 ", if the indicator was disclosed with general presentation or only with quantitative presentation without specific explanation, the label is " 1 ", if the indicator was disclosed with specific information about activities, the label is " 2 ". However, in order to ensure reliability when calculating these indicators, the authors analyzed the content of the enterprises' reports in the following process:

Firstly, the authors used two assistants to analyze the content of the annual reports and sustainable development reports of enterprises. The two assistants must be knowledgeable in accounting, financing and CSR issues.

Secondly, the content of corporate social responsibility in this study was discussed and communicated to two assistants by the authors. Besides, two assistants were required to understand indicators of information which needed to be checked in the list of corporate social responsibility information which authors tested and made necessary adjustment.

Thirdly, the authors assigned tasks to assistants and worked at the same time to analyze content of the reports of the enterprises and give appropriate label for each indicators of information. The indexes found would be marked and recorded carefully. Assistants and authors worked independently and did not see the results of the others.

Fourth, cross-check was carried out with the results of assistants and the results of the authors. If there were differences, they would check again, analyze and discuss to make the final decisions.

After determining the score for each indicator of each enterprise in each year, the level of CSRD was determined using the following formula:

$\operatorname{CSRDj}=\sum_{i}^{n} X \mathrm{ij}$

In which:

CSRDj: indicator of information disclosures of $j^{\text {th }}$ enterprise

$\mathrm{Xij}=0$ if $\mathrm{i}^{\text {th }}$ indicator of information is not disclosed in enterprise $\mathrm{j}$

$\mathrm{Xij}=1$ if $\mathrm{i}^{\text {th }}$ indicator of information disclosed in enterprise $\mathrm{j}$ is general information or quantitative information without specific explanation

$\mathrm{Xij}=2$ if $\mathrm{i}^{\text {th }}$ indicator of information disclosed in enterprise $\mathrm{j}$ is detailed information about specific activities

\subsubsection{Dependent Variables-Market Value of Enterprises}

In this study, the authors selected both market value compared to book value Tobin'Q (TBQ) to measure corporate value. TBQ is a modern financial measuring tool introduced by James Tobin in 1971 to reflect the market value of total assets compared to the book value of total assets (Tobin, 1971). In this research, TBQ is measured using the following formula: 


\section{Market value of enterprise' equity + Book value of liabilities}

\section{Tobin's $Q=$ Book value of total assets}

In which: market value of enterprise' equity = share price $x$ the number of outstanding shares

\subsubsection{Control Variables}

The variables SIZE, LEV, GRW were selected to be control variables of the model. Those are variables used by many authors when analyzing corporate profits. They are important factors influencing the estimation of variables that affect corporate financial performance.

Corporate size (SIZE). Bayoud et al. (2012) argued that large-scale enterprises are likely to generate more profits than smaller ones. Therefore, the size of enterprises is considered an important factor affecting the relationship between CSRD and corporate financial performance.

Leverage (debts/equity) ( $L E V$ ). Financial leverage is used by research as a factor affecting corporate financial performance. Researchers argued that when a company is dominated by creditors, its financial performance may be affected (Nguyen \& Doan, 2017). Therefore, financial leverage is necessary in the model to test the correlation between CSRD and corporate financial performance.

Revenue growth (GRW). A study of Zeitun (2014) on capital structure and corporate performance of Jordanian countries demonstrated that revenue growth has a positive effect on corporate performance. The author explained that corporates with high growth rate will have better results because they can have more investment opportunities and more profits.

\subsection{Data Analysis}

To examine the positive relationship between corporate social responsibility and market value of enterprises, the author developed the regression equation between the dependent variable TBQ and CSRD, as follows:

$$
\text { (1) } \mathrm{TBQ}_{\mathrm{i}, \mathrm{t}}=\beta_{\mathrm{o}}+\beta_{1} \mathrm{CSRD}_{\mathrm{i}, \mathrm{t}}+\beta_{2} \mathrm{SIZE}_{\mathrm{i}, \mathrm{t}}+\beta_{3} \mathrm{LEV}_{\mathrm{i}, \mathrm{t}}+\beta_{4} \mathrm{GRW}_{\mathrm{i}, \mathrm{t}}+\mathrm{u}_{\mathrm{i}, \mathrm{t}}
$$

In addition, some authors have demonstrated that the practice and disclosures of corporate social responsibility affect financial performance of enterprises in the future (Makni et al. 2009) (Elena Platonova et al., 2009) (Jitaree (2015) (Nguyen Xuan Hung \& Trinh Hiep Thien, 2016). The authors explained that the CSRD contributes to improving the image of the enterprises, thereby improving the value of the enterprises in the future. Therefore, the authors developed the second regression equation as follows:

$$
\text { (2) } \mathrm{TBQ}_{\mathrm{i}, \mathrm{t}}=\beta_{\mathrm{o}}+\beta_{1} \mathrm{CSRD}_{\mathrm{i}, \mathrm{t}-1}+\beta_{2} \mathrm{SIZE}_{\mathrm{i}, \mathrm{t}}+\beta_{3} \mathrm{LEV}_{\mathrm{i}, \mathrm{t}}+\beta_{4} \mathrm{GRW}_{\mathrm{i}, \mathrm{t}}+\mathrm{u}_{\mathrm{i}, \mathrm{t}}
$$

In this study, the authors used panel data in regression analysis. Panel data has many advantages over time-series data and spatial data (cross-section data) because it allows 
studying of complex models fluctuating in both directions. In this study, the authors used the Ordinary Least Squares regression (Pooled OLS), Fixed effects model (FEM), Random effects model (REM), The Generalized Least Square (GLS), Two-stage least squares 2SLS regression to find the best model for research data.

\section{Research Results and Discussion}

\subsection{Descriptive Statistics}

The survey on level of CSRD in 43 listed enterprises during the period from the 2006 to 2016 showed that the average level of CSRD increased steadily. This indicates that enterprises have gradually concerned more about CSRD and focused on the objectives of long-term development and bringing benefits for community.

Table 3. Statistical results of average level of information disclosures of enterprises from 2006 to 2016

\begin{tabular}{|c|c|c|}
\hline Year & Total score of average CSRD & Indicators of average CSRD \\
\hline$(1)$ & $(2)$ & $(3)=(2) / 35$ indicators \\
\hline 2006 & 9.12 & 0.26 \\
\hline 2007 & 11.30 & 0.32 \\
\hline 2008 & 13.09 & 0.37 \\
\hline 2009 & 14.67 & 0.42 \\
\hline 2010 & 15.56 & 0.44 \\
\hline 2011 & 16.33 & 0.47 \\
\hline 2012 & 17.74 & 0.51 \\
\hline 2013 & 18.63 & 0.53 \\
\hline 2014 & 19.42 & 0.55 \\
\hline 2015 & 21.40 & 0.61 \\
\hline 2016 & 22.53 & 0.64 \\
\hline
\end{tabular}

Source: results of data analysis based on Stata 12 .

Detailed information on average levels of CSRD on environment (ENV), responsibilities to employees (EMP), responsibilities to community (COM), responsibilities to customers (CUS) indicates that the level of environmental disclosures is the lowest. This means that Vietnamese enterprises have not truly concerned about environmental responsibilities. The activities of waste disposal, pollution control in the business process, strategies to support environmental protection activities have not been given due consideration by enterprises. This is the difference between Vietnam and developed countries in Europe, where enterprises focus on information disclosures of environment, energy, recycling, pollution caused by the pressure from customers, investors on the environmental protection of enterprises. Information about the responsibilities to customers is published the most by enterprises including information on product quality, safety level of products, production process. This 


\section{Macrothink}

shows that Vietnamese companies are most likely to focus on customers with the desire to pass this information to promote their products to consumers.

Table 4. Statistical results of components of CSRD of enterprises from 2006 to 2016

\begin{tabular}{|l|l|l|l|l|l|l|l|l|}
\hline Indicators & Env mean & $\begin{array}{l}\text { Indicator } \\
\text { env }\end{array}$ & $\begin{array}{l}\text { Emp } \\
\text { mean }\end{array}$ & $\begin{array}{l}\text { Indicator } \\
\text { emp }\end{array}$ & com mean & $\begin{array}{l}\text { Indicator } \\
\text { com }\end{array}$ & $\begin{array}{l}\text { Cus } \\
\text { mean }\end{array}$ & $\begin{array}{l}\text { Indicator } \\
\text { cus }\end{array}$ \\
\hline Total & 2.084567 & 0.21 & 6.881607 & 0.57 & 3.112051 & 0.39 & 4.95 & 0.99 \\
\hline
\end{tabular}

Source: results of data analysis based on Stata 12.

\subsection{Correlation Analysis}

Table 5. Correlation coefficient among variables in the model

\begin{tabular}{|l|l|l|l|l|l|l|}
\hline Variables & TBQ & CSRD & CSRD (-1) & SIZE & LEV & GRW \\
\hline tbq & 1 & & & & & \\
\hline csrd & 0.4149 & 1 & & & & \\
\hline csrd(-1) & 0.4069 & 0.9607 & 1 & & & \\
\hline size & 0.0484 & 0.4069 & 0.4017 & 1 & & \\
\hline lev & -0.1669 & -0.2874 & -0.2725 & 0.1881 & 1 & \\
\hline grw & 0.0567 & 0.014 & -0.0298 & 0.0459 & -0.0379 & 1 \\
\hline & & & & & & \\
\hline
\end{tabular}

Source: results of data analysis based on Stata 12.

Table 5 shows that CSRD in the previous year and the present year have a relatively high correlation with the market value of the enterprise Tobin'Q. This indicates enterprises with more information disclosures have positive signals for corporate stock prices. In addition, table 3 also shows that the corporate market value is positively correlated with firm size, growth rate, but negatively correlated with debt to equity ratio. This shows that enterprises having high market value are large-scale enterprises with high revenue growth rates and low debt to equity ratio. 


\section{Macrothink}

5.3 Regression Analysis

Table 6. Results of regression analysis of dependent variables TBQ

\begin{tabular}{|l|l|l|l|l|l|l|}
\hline \multirow{2}{*}{ Variables } & \multicolumn{7}{|l|}{ Model 1-TBQ } & Model 2-TBQ & REM \\
\cline { 2 - 7 } & OLS & FEM & REM & OLS & FEM & REM \\
\hline CSRD & $0.040795^{* * *}$ & 0.009723 & $0.024844^{* * *}$ & & & \\
\hline CSRD(-1) & & & & $0.0447^{* * *}$ & 0.014745 & $0.027778^{* * *}$ \\
\hline SIZE & $-0.12167^{* * *}$ & $-0.85285^{* * *}$ & $-0.23468^{* * *}$ & $-0.1061^{* * * *}$ & $-0.66328^{* * *}$ & $-0.14921^{* *}$ \\
\hline LEV & 0.008411 & $0.262415^{* * *}$ & 0.050179 & -0.0136 & $0.202264^{* *}$ & -0.01597 \\
\hline GWR & 0.139478 & 0.067406 & 0.132718 & $0.1742^{* *}$ & 0.124048 & $0.173103^{*}$ \\
\hline cons & $4.074958^{* * *}$ & $24.39556^{* * *}$ & $7.394366^{* * *}$ & $3.5334^{* * *}$ & $19.13517^{* * *}$ & $4.990672^{* * *}$ \\
\hline N & 473 & 473 & 473 & 430 & 430 & 430 \\
\hline $\begin{array}{l}\text { Hausman } \\
\text { Prob>chi2 }\end{array}$ & 0.0000 & & & 0.0000 & \\
\hline Prob>F & 0.0000 & \multicolumn{7}{|l|}{} & & \\
\hline
\end{tabular}

Source: results of data analysis based on Stata 12.

In both models (1) and (2), the authors applied Fixed Effects Model (FEM) and Random Effects Model (REM). Based on results of FEM and REM, the authors used Hausman test to compare the selection of FEM or REM. The result of Prob $>$ chi2 $=0.000$ means that P_value $=0.000<\alpha=5 \%$, thus there is enough evidence to reject Ho. In this case, the Fixed Effect Model (FEM) is more suitable than Random Effects Model (REM).

After selecting the FEM instead of the REM, the authors carried out Ordinary Least Squares regression (OLS) and applied $F$ test to select the appropriate model between the FEM and the OLS. The results of $\mathrm{F}$ test show that Prob $>\mathrm{F}=0.000<\alpha=5 \%$, then reject Ho, select FEM.

Thus, with the data collected, the FEM is the best selection. However, before analyzing the relationship between CSRD and corporate market value, the authors conducted validation tests and makes necessary corrections to overcome limitations of the model.

\subsubsection{Detecting Multi-Collinearity}

In order to check if the multi-collinearity exists in the selected model from regression analysis, the authors used VIF-Variance Inflation Factor. There are several proposals for VIF values, but the maximum value is 10 . However, there are some studies suggesting that if VIF is higher than 5, multi-collinearity may be present (Pan \& Jackson, 2008). 
Table 7. Results of VIF checking with dependent variable TBQ

\begin{tabular}{|c|c|c|c|c|}
\hline \multirow[t]{2}{*}{ Variable } & \multicolumn{2}{|c|}{ Model 1} & \multicolumn{2}{|c|}{ Model 2} \\
\hline & VIF & 1/VIF & VIF & 1/VIF \\
\hline CSRD & 1.43 & 0.69925 & & \\
\hline $\operatorname{CSRD}(-1)$ & & & 1.41 & 0.708815 \\
\hline SIZE & 1.36 & 0.733349 & 1.36 & 0.737703 \\
\hline LEV & 1.22 & 0.819272 & 1.23 & 0.815703 \\
\hline GRW & 1 & 0.995044 & 1.01 & 0.989709 \\
\hline Mean VIF & 1.25 & & 1.25 & \\
\hline
\end{tabular}

Source: results of data analysis based on Stata 12.

Both equations have VIFs less than 5, therefore it is unlikely that multi-collinearity exists.

\subsubsection{Heteroskedasticity Test}

The modified Wald was used to check heteroskedasticity. Ho: there is no heteroskedasticity in the model. If the test gives $\mathrm{P}_{-}$value $<\alpha=0.05$, Ho is rejected and H1, which says there is heteroskedasticity in the model, is accepted. The results of the test are displayed in table 8:

Table 8 . Results of heteroskedasticity test

\begin{tabular}{|l|l|l|}
\hline Model 1 & chi2 $(43)=21735.13$ & There is heteroskedasticity \\
& Prob $>$ chi $2=.0000$ & \\
\hline Model 2 & chi2 $(43)=1625.78$ & There is heteroskedasticity \\
& Prob $>$ chi2 $=0.0000$ & \\
\hline
\end{tabular}

Source: results of data analysis based on Stata 12 .

\subsubsection{Checking Auto-Correlation}

Auto-correlation was checked with Wooldridge test. Ho: there is no auto-correlation. If the test result shows $P_{-}$value $<\alpha=0.05$, Ho is rejected and H1 is accepted, which means there is auto-correlation in the model. The test results is shown in table 9: 


\section{Macrothink}

Table 9. Results of auto-correlation test

\begin{tabular}{|l|l|l|}
\hline Model 1 & $\begin{array}{l}\mathrm{F}(1,42)=4.594 \\
\text { Prob }>\mathrm{F}=0.0379\end{array}$ & There is auto-correlation \\
\hline Model 2 & $\begin{array}{l}\mathrm{F}(1,42)=39.078 \\
\text { Prob }>\quad \mathrm{F}=0.0000\end{array}$ & There is auto-correlation \\
\hline
\end{tabular}

Source: results of data analysis based on Stata 12 .

\subsubsection{Checking Endogenous Phenomena}

Endogenous phenomena occur when independent variables are influenced by other variables in the model. Endogenous phenomena may lead to serious errors in regression analysis since this estimation is divergent and unsteady (Nguyen \& Hoang, 2015). In this study, endogenous phenomena can occur due to reciprocal relationship between CSRD and corporate financial performance. Although Jitaree (2015) pointed out the endogenous problem in CSRD and TBQ, however, in this study, the authors also examined the endogenous relationship between these variables. To check the endogenous phenomena of independent variables in models (1), (2) the author used the Durbin- Wu- Hausman Test with hypothesis Ho: variable is exogenous. If the test result shows $\mathrm{P}_{-}$value $<\alpha=0.1$, Ho can be rejected which means the variable is endogenous. The test results are shown in Table 10:

Table 10. Results of endogenous phenomena test

\begin{tabular}{|l|l|l|}
\hline Model 1 & $\begin{array}{l}\mathrm{F}(1,429)=2.91 \\
\text { Prob }>\quad \mathrm{F}=0.0888\end{array}$ & There are endogenous phenomena \\
\hline Model 2 & $\begin{array}{l}\mathrm{F}(1, \quad 386)=0.51 \\
\text { Prob }>\mathrm{F}=0.4746\end{array}$ & There are no endogenous phenomena \\
\hline
\end{tabular}

Source: results of data analysis based on Stata 12.

Based on results of table $8,9,10$, summary of defects in models is shown table 11 as follows:

Table 11. Summary of defects in models

\begin{tabular}{|c|c|c|c|}
\hline Model & Auto-correlation & Heteroskedasticity & Endogenous phenomena \\
\hline 1 & Yes & Yes & Yes \\
\hline 2 & Yes & Yes & No \\
\hline
\end{tabular}

Source: Created by the authors. 


\subsubsection{Regression Analysis with Models}

To overcome defects of the model, the author used different regression methods depending on the types of defects.

\section{Regression analysis result of model 1}

To overcome the endogenous phenomena in model 1, in this study, the authors used two-stage least squares regression model (2SLS) to examine the relationship between CSRD and corporate value. In order to control potential deviations, instrument variables need to be exogenous variables corresponding to endogenous variables CSRD of the 2SLS regression. Thus, the instrument variables that can be used for two-stage least squares regression 2SLS of the endogenous relationship between CSRD and corporate value are audit quality variable (Audit) and law variable (Law). Which means enterprises audited by large auditing firms (Big 4) have a higher level of CSRD (Nguyen et al., 2017) (Kelly \& Buranatrakul 2017). This variable is determined as follows: the enterprise audited by Bigfour is labeled "1" and enterprise not audited by Bigfour is labeled "0". Apart from Audit, the author used the second tool, Law. If there are mandatory requirements of the law, the level of CSRD is higher. This has been confirmed by the survey of the KMPG (2013) showing that the percentage of firms reporting corporate social responsibility increased by 37\% from 2011 to 2013 as some markets such as Singapore, South Africa, the United States, India , Indonesia have tightened mandatory requirements for social responsibility reporting. In Vietnam, in 2015, the Ministry of Finance issued Circular 155/2015/TT-BTC mandatorily requiring listed enterprises to have environmental and social reports. Thus, the Law variable in this study is labeled as "1" with 2015 or 2016 and "0" with the remaining years. The regression equation between instrument variables and endogenous variables is shown as follows:

$\operatorname{CSRD}=\beta_{\mathrm{o}}+\beta_{1} \operatorname{AUDIT}_{\mathrm{i}, \mathrm{t}}+\beta_{2} \mathrm{LAW}_{\mathrm{i}, \mathrm{t}}+€_{\mathrm{i}, \mathrm{t}}$

The authors conducted regression analysis OLS, FEM, REM to verify the relationship between instrument variables Audit, Law and endogenous variables Csrd. The regression results are shown in Table 12:

Table 12. Regression analysis between instrument variables and endogenous variables

\begin{tabular}{|c|c|c|c|c|c|c|}
\hline CSRD & OLS & & FEM & & & \\
\hline & Coef. & $\mathrm{P}>\mathrm{t}$ & Coef. & $\mathrm{P}>\mathrm{t}$ & Coef. & $\mathrm{P}>\mathrm{t}$ \\
\hline audit & 8.05575 & 0 & 6.270754 & 0 & 6.221204 & 0 \\
\hline law & 5.755859 & 0 & 4.33118 & 0 & 4.689608 & 0 \\
\hline cons & 12.36873 & 0 & 13.6295 & 0 & 13.50817 & 0 \\
\hline $\begin{array}{l}\text { Hausman } \\
\text { Prob }>\text { chi2 }\end{array}$ & & & \multicolumn{4}{|c|}{0.000} \\
\hline Prob $>F$ & \multicolumn{4}{|c|}{0.000} & & \\
\hline
\end{tabular}

Source: results of data analysis based on Stata 12 . 


\section{Ml Macrothink}

This result shows that the selection of instrument variables is appropriate. This means that if listed companies are audited by audit firms Big 4 and more laws are enforced, the level of CSRD will be increased.

Then, auditors conducted 2SLS (IV (2SLS) estimation) with dependent variable TBQ, dependent variable CSRD and instrument variables AUDIT, LAW. Results of regression analysis are shown in table 13:

Table 13. Results of regression analysis 2SLS of variables TBQ and CSRD

\begin{tabular}{|l|l|l|l|l|l|l|}
\hline Tbq & Coef. & Std. Err. & $\mathbf{z}$ & $\mathbf{P}>\mathbf{z}$ & [95\% Conf. & Interval] \\
\hline Csrd & 0.081556 & 0.0376 & 2.17 & 0.03 & 0.007861 & 0.155251 \\
\hline Size & -1.39147 & 0.29525 & -4.71 & 0.00 & -1.97015 & -0.81279 \\
\hline Lev & 0.331186 & 0.082554 & 4.01 & 0.00 & 0.169383 & 0.49299 \\
\hline Grw & 0.075779 & 0.094686 & 0.8 & 0.424 & -0.1098 & 0.261359 \\
\hline Sargan statistic (over-identification test ofall instruments): 3.71 \\
\hline \multicolumn{6}{|l|}{ Chi-sq(1) P-val = 0.0541 } \\
\hline
\end{tabular}

Source: results of data analysis based on Stata 12 .

Before analyzing test results of 2SLS, the authors assessed the completeness and validity of instrument variables used in the 2SLS regression by Sargan test. Sargan test has hypothesis $\mathrm{H}_{0}$ : the instrument variable is exogenous, which is not correlated with model error (Hansen et al. 1996). The results of Table 11 show that $\mathrm{p}$-value $=0.0541>0.05$ so $\mathrm{H}_{0}$ is accepted, which means the model has enough necessary instrument variables.

Assuming other factors are constant, there is a positive relationship between CSRD and the market value of the firm (coefficient $\beta=0.081$ and sig $=0.03$ ). This finding is consistent with the authors' predictions and coincides with some studies (Cahan et al. (2015) (Makni et al. 2009) (Platonova et al. 2016). This means that good CSRD will bring value to the business.

\section{Regression analysis results of model 2}

To overcome the Heteroskedasticity phenomena and auto-correlation in the research model, the authors used the Generalized Least Square (GLS). The GLS regression results of the model 2 are shown in Table 14. 
Table 14. The GLS regression analysis results of model 2

\begin{tabular}{|l|l|l|l|l|l|l|}
\hline \multicolumn{1}{|c|}{ Tbq } & \multicolumn{1}{c|}{ Coef. } & \multicolumn{1}{c|}{ Std. Err. } & \multicolumn{1}{c|}{$\mathbf{z}$} & \multicolumn{1}{c|}{$\mathbf{P}>\mathbf{z}$} & \multicolumn{2}{c|}{ [95\% Conf.Interval] } \\
\hline Csrd(-1) & 0.044717 & 0.005005 & 8.93 & 0.000 & 0.034907 & 0.054528 \\
\hline Size & -0.10608 & 0.038892 & -2.73 & 0.006 & -0.18231 & -0.02985 \\
\hline Lev & -0.01361 & 0.05295 & -0.26 & 0.797 & -0.11739 & 0.090168 \\
\hline Grw & 0.174169 & 0.099724 & 1.75 & 0.081 & -0.02129 & 0.369625 \\
\hline cons & 3.533449 & 1.018852 & 3.47 & 0.001 & 1.536535 & 5.530362 \\
\hline
\end{tabular}

Source: results of data analysis based on Stata 12 .

Table 14 shows positive relationship between CSRD in the previous year and the market value of the enterprise (coefficient $\beta=0.044$ and sig $=0.00$ ). This is consistent with the prediction of the authors that CSRD contributes to improving the image of the enterprise, thereby improving the value of enterprise in the future. Similar results have been confirmed in studies of Jitaree (2015), Nguyen \& Trinh (2016).

\section{Conclusion}

The actual survey showed that the level of practice and disclosures of corporate social responsibility of listed companies on the stock market in Vietnam is still low. However, these activities have been improved over time. This shows that Vietnamese enterprises have increasingly concerned about social activities with the objective of sustainable development for businesses and the whole society. The results from the regression analysis of relationship between CSRD and value of enterprise showed that the practice of corporate social responsibility of business has a positive impact on the market value of listed companies on the stock market of Vietnam. Although the level of impact is low, this shows a positive sign of the activities and information disclosures about corporate responsibility to the environment, lives of employees, investment in training and developing human resources, community support and development, and especially information on product quality contributing to enhancing corporate value. Many enterprises are afraid of costs and resources occuring to implement and report corporate social responsibility, but the results of this research showed that the costs of enterprises will be offset by benefits such as creating a prestigious image for enterprises, boosting sales, and increasing brand value. In addition, this study also showed that impact from Vietnamese government has also led to an increase in the level of CSRD of listed companies in the market. This result suggests that an investment strategy for social responsibility and enhancing information transparency will boost business performance. Last but not least, this result is also a basis for Vietnamese government to adopt more regulations on CSRD to meet the needs of international economic integration.

The results suggest that:

- The Vietnamese government: introduce more regulations on CSRD for enterprises, especially those listed on the Vietnam's stock market. This is necessary to meet the needs of international economic integration. 
- The enterprises: recognize the importance of social and environmental information disclosures as an opportunity to legalize products and shares of enterprises in the eyes of consumers and investors. Therefore, companies need to develop specific strategies to enhance the practice and effective disclosure of corporate social responsibility.

- The investors: find more information on social responsibility that enables them to have better assessment of shares of companies.

\section{Limitations and Recommendations for Future Research}

In the world, there have been many studies on the impact of CSRD on corporate value. These studies used different measurements so the results vary considerably. There are many reasons for that, specifically when it is not easy to measure the level of CSRD because social responsibility is a broad concept. In this study, the authors used the content analysis method for the annual reports and the sustainable development reports of the enterprises based on the lists of surveys which were built and adjusted according to the references of previous studies. Thus, the indicators of corporate social responsibility developed by the authors are inevitably subjective. Therefore, in the future, when Vietnam's economy grows and standards of CSRD are standardized, measurement of information disclosures will be easier and more reliable.

\section{References}

Alexander, G. J., \& Buchholz, R. A. (1978). Corporate Social Responsibility and Stock Market Performance. The Academy of Management Journal, 21(3), 479-486. https://doi.org/10.2307/255728

Anderson, J. V., \& Frankle, A. W. (1980). Voluntary Social Reporting: An IsoBeta Portfolio Analysis.

Bayoud, N. S., Kavanagh, M., \& Slaughter, G. (2012). An empirical study of the relationship between corporate social responsibility disclousure and organizational performance:evidence from Libya. International Journal of Management and Marketing Research, 5(3), 69-82.

Belkaoui, A. (1976), The Impact of the Disclosure of the Environmental Effects of Organizational Behavior on the Market. Financial Management, 5(4), 26-31. https://doi.org/10.2307/3665454

Berthelot, S., Coulmont, M., \& Serret, V. (2012). Do Investors Value Sustainability Reports? A Canadian Study. Corporate Social Responsibility and Environmental Management. https://doi.org/10.1002/csr.285

Blacconiere, W. G., \& Northcut, W. D. (1997). Environmental information and market reactions to environmental legislation. Journal of Accounting, Auditing \& Finance, 12(2), 149-178.

Blacconiere, W. G., \& Pattenb, D. M. (1994). Environmental disclosures, regulatory costs, and changes in firm value. Departmenr of Accounting, Indiana University. Bloomington. IN 47405-1701, USA b Illinois State University, Normal, IL 61761-6901, USA. 
Blundell, R., \& Bond, S. (1998). Initial conditions and moment restrictions in dynamic panel data models. Journal of Econometrics, $87, \quad 115-143$. https://doi.org/10.1016/S0304-4076(98)00009-8

Branco, M., \& Rodrigues, L. (2006). Corporate social responsibility and resource-based perspectives. Journal of Business Ethics, 69(2), 111-32. https://doi.org/10.1007/s10551-006-9071-z

Cahan, S. F., Villiers, C. D., Jeter, D. C., Naiker, V. \& Van Staden, C. J. (2015). Are CSR Disclosures Value Relevant? Cross-Country Evidence. European Accounting Review. http://dx.doi.org/10.1080/09638180.2015.1064009

Clarkson, P. M., Fang. X., Li, Y., \& Richardson, G. (2013). The relevance of environmental disclosures: Are such disclosures incrementally informative?

Dewi, K., \& Monalisa, M. (2016). Effect of corporatr social responsibility discloure on financial performance with audit as a moderatin variable. Binus Business Review, 149-155. https://doi.org/10.21512/bbr.v7i2.1687

Dowling, J., \& Pfeffer, J. (1975). Organizational Legitimacy: Social Values and Organizational Behavior. Pacific Sociological Review, 18, 122-136. https://doi.org/10.2307/1388226

Dragomir, V. D. (2010). Environmentally sensitive disclosures and financial performance in a European setting. Journal of Accounting \& Organizational Change, 6(3), 359-388. https://doi.org/10.1108/18325911011075222

Edmund, J. B., Mark, M. H., \& Ghon, S. R. (1997). Stock market reaction to ethical initiatives of defense contractors: theory and evidence. Critical Perspectives on Accounting, 8 , 541-561. https://doi.org/10.1006/cpac.1997.0124

Edward Freeman, R. (1984). Strategic Management: A Stakeholder Approach. Pitman Publishing. Retrieved from http://www.worldcat.org/title/strategic-management-a-stakeholder-approach/oclc/9685996

Freedman, M., \& Stagliano, A. J. (1991). Differences in Social-Cost Disclosures: A Market Test of Investor Reactions. Accounting, Auditing \& Accountability Journal, 4(1). https://doi.org/10.1108/09513579110142480

Gray, R., Kouhy, R., \& Lavers, S. (1995). Corporate social and environmental reporting: a review of the literature and a longitudinal study of UK disclosure. G Auditing \& Accountability Journal, 8(2), 47-77. https://doi.org/10.1108/09513579510146996

Gunawan, J., Djajadikerta, H., \& Smith, M. (2009). An examination of corporate social discloures in the annual reports of indonesian listed companies. Joural of Asia Pacific Centre for Environmental Accountability, 13-39.

Guthrie, J., \& Parker, L. D. (1989). Corporate social reporting: a rebuttal of legitimacy theory. Accounting and Business Research, 19(76), 343-352. 
Hansen, L. P., Heaton, J., \& Yaron, A. (1996). Finite-Sample Properties of Some Alternative GMM Estimators. Journal of Business \& Economic Statistics, 14(3), 262-280.

Hassel, L., Nilsson, H., \& Nyquist, S. (2005). The value relevance of environmental performance. European Accounting Review, 14(1), 41-61.

Ho, N. T. T., \& Yekini, L. S. (2014). Investigating the link between CSR and Financial performance-Evidence from Vietnamese listed companies. British Journal of Arts and Social Sciences.

Ho, V. T., \& Ho, T. V. A. (2017). Corporate Social Responsibility and Financial Effectiveness: Evidence from Vietnam's Listed Companies. Economic \& Development, $36-43$.

Jitaree, W. (2015). Corporate social responsibility disclosure and financial performance: evidence from Thailand. Pacific Sociological Review, 18, 122-136.

Kelly, A. V., \& Buranatrakul, T. (2017). EXAMINING CSR DISCLOSURE IN VIETNAM: Examining CSR disclosure in Viet Nam: too litte, too late. International Journal of Business and Economic, 9(1), 63-81.

Klerk, M. D., Villiers, C. D., \& Staden, C. V. (2015), The influence of corporate social responsibility disclosure on share prices: Evidence from the United Kingdom. Accounting Review, 27(2), 208-228. https://doi.org/10.1108/PAR-05-2013-0047

Khlif, H., Guidara, A., \& Souissi, M. (2015). Corporate social and environmental disclosure and corporate performance: Evidence from South Africa and Morocco. Journal of Accounting in Emerging Economies, 5(1), 51-69. https://doi.org/10.1108/JAEE-06-2012-0024

Lu, Y., Abeysekera, I., \& Cortese, C. (2015). Corporate social responsibility reporting quality, board characteristics and corporate social reputation Evidence from China. Pacific Accounting Review, 27(1), 95-118. https://doi.org/10.1108/PAR-10-2012-0053

Mahoney, L., \&Roberts, R. W. (2007). Corporate social performance, financial performance and institutional ownership in Canadian firms. Accounting Forum, 31(3), 233-53. https://doi.org/10.1016/j.accfor.2007.05.001

Makni, R., Francoeur, C., \& Bellavance, F. (2009). Causality Between Corporate Social Performance and Financial Performance: Evidence from Canadian Firms. Journai of Business Ethics, 409-422. https://doi.org/10.1007/s10551-008-0007-7

Mohammed, N. A., Zakaree, S., \& Oladele, O. K. (2016). Corporate Social Responsibility Disclosure and Financial Performance of Listed Manufacturing Firms in Nigeria. Research Journal of Finance and Accounting, 7(4), 47-58.

Murray, A., Sinclair, D., Power, D., \& Gray, R (2005). Do Financial Markets Care About Social And Environmental Disclosure? Further Evidence And Exploration From The Uk. Auditing \& Accountability Journal, 19(2), 228-255. 
Nguyen, L. S. et al. (2017). Factors Affecting Disclosure Levels of Environmental Accounting Information: The Case of Vietnam. Accounting and Finance Research, 6(4).

Nguyen, T. B. N. et al. (2015). Association between Corporate Social Responsibility Disclosures and Firm Value-Empirical Evidence fromVietnam. International Journal of Accounting and Financial Reporting, 2162-3082.

Nguyen, T. M. H., \& Đoan, T. L. (2017). The Impact of Ownership Structure on Performance of Listed Companies in Vietnam's Stock Market. Journal of Science, 23-33.

Nguyen, T. M., \& Hoang, B. P. (2015). Scattered about endogenous issues in economic analysis. Scientific Research, National Economics University.

Nguyen, X. H., \& Trinh, H. T. (2016). Relationship between investmennt of sustainable development and financial results under quality control of finanical reports. Summary report of conference. Hanoi University of Industry.

Platonova, E., Asutay, M., Dixon, R., \& Mohammad, S. (2016). The Impact of Corporate Social Responsibility Disclosure on Financial Performance: Evidence from the GCC Islamic Banking Sector. Journal of Business 1-21. https://doi.org/10.1007/s10551-016-3229-0

Robert, W. (1978). An Investigation of the Information Content of (Certain) Social Responsibility Disclosures Ingram. Journal of Accounting Research, 16(2), 270.

Saleh, M., Zulkifli, N., \& Muhamad, R. (2011). An Empirical Examination of the Relationship between Corporate Social Responsibility Disclosure and Financial Performance in an Emerging Market. Asia-Pacific Journal of Business Administration, 3(2), 165-190. https://doi.org/10.1108/17574321111169849

Tjia, O., \& Setiawati, L. (2012). Effect of CSR Disclosure to Value of the Firm: Study for Banking Industry in Indonesia. World Journal of Social Sciences, 2(6),169-178.

Verbeeten, F. H. M., Gamerschlag, R., \& Möller, K. (2016). Are CSR disclosures relevant for investors? Empirical evidence from Germany. Management Decision, 54(6), 1359-1382. https://doi.org/10.1108/MD-08-2015-0345

Zeitun, R. (2014). Corporate Governance, Capital structure and corporate performance: evidence from GCC Countries. Review of Middle East Economics and Finance, 75-96. https://doi.org/10.1515/rmeef-2012-0028

\section{Copyrights}

Copyright for this article is retained by the author(s), with first publication rights granted to the journal.

This is an open-access article distributed under the terms and conditions of the Creative Commons Attribution license (http://creativecommons.org/licenses/by/4.0/). 